Indonesian Journal of Pharmaceutical Science and Technology Journal Homepage : http://jurnal.unpad.ac.id/ijpst/

\title{
Comparative Study of Antioxidant Phycocyanin Extracts Activity between S. platensis with S. fusiformis Using DPPH Method
}

\author{
Dwi Margiati*, Danni Ramdhani, Asri P. Wulandari
}

Fakultas Farmasi Universitas Padjadjaran, Jatinangor, Sumedang - Indonesia

Submitted 17 April 2017; Revised 5 August 2017; Accepted 28 June 2018; Published 27 June 2019

*Corresponding author: dwimargiati1302@gmail.com

\begin{abstract}
Phycocyanin is Spirulina's content which has antioxidant activity to inhibit oxidation process or formation of free radicals that play a role in the initiation high-degenerative diseases. This research is aim to determine the best antioxidant activity of S. platensis with S. fusiformis through the best extraction methods of Spirulina cell between distilled water and PBS (Phosphate Buffer Solution). This research method existed Spirulina cell extraction used distilled water and PBS, and then followed by fractionation and dialysis phycocyanin extract, afterward tested the antioxidant activity used DPPH method. The result of extraction used PBS with a salt concentration of ammonium sulfate $30 \%$ produced the best purity value of phycocyanin extract of both types of Spirulina. Results of tested the antioxidant activity, S. fusiformis has the best antioxidant activity compared with $S$.platensis with a value of $311.43 \mathrm{ppm}$ and $387.36 \mathrm{ppm}$, respectively.
\end{abstract}

Keywords: Antioxidant, DPPH, Phycocyanin extracts, S. fusiformis, S. platensis.

\section{Studi Komparatif Aktivitas Antioksidan Ekstrak Fikosianin S. platensis dengan S. fusiformis Menggunakan Metode DPPH}

\begin{abstract}
Abstrak
Fikosianin merupakan kandungan dalam Spirulina yang memiliki aktivitas antioksidan untuk menghambat proses oksidasi atau pembentukan radikal bebas yang berperan tinggi dalam inisiasi penyakit degeneratif. Penelitian ini bertujuan untuk mengetahui aktivitas antioksidan terbaik antara jenis $S$. platensis dengan S. fusiformis melalui metode ekstraksi terbaik sel Spirulina antara aquadest dan PBS (Phosphate Buffer Solution). Metode penelitian ini meliputi ekstraksi sel Spirulina dengan menggunakan aquadest dan PBS, lalu dilanjutkan dengan fraksinasi dan dialisis ekstrak fikosianin, serta pengujian aktivitas antioksidan menggunakan metode DPPH. Hasil ekstraksi menggunakan PBS dengan konsentrasi garam Ammonium sulfat 30\% menghasilkan nilai kemurnian ekstrak fikosianin terbaik dari kedua jenis Spirulina. Hasil pengujian aktivitas antioksidan, ekstrak fikosianin S. fusiformis memiliki aktivitas antioksidan terbaik dibandingkan dengan S. platensis dengan nilai 311,43 ppm dan 387,36 ppm masing-masingnya.
\end{abstract}

Kata Kunci: Antioksidan, DPPH, Ekstrak Fikosianin, S. fusiformis, S. platensis. 


\section{Pendahuluan}

Antioksidan adalah zat yang mampu mencegah pembentukan reaksi radikal bebas (peroksida) dalam oksidasi lipid atau senyawa yang menunda, memperlambat dan mencegah proses oksidasi. ${ }^{1}$ Proses oksidasi tersebut dikenal sebagai tekanan oksidatif (oxidative stress) yang dapat menyebabkan kerusakan sel-sel jaringan dan enzim-enzim. Keadaan tersebut dapat menginisiasi terjadinya penyakit degeneratif seperti jantung koroner, katarak, gangguan kognisi dan kanker. ${ }^{2}$

Radikal bebas yang merupakan molekul yang tidak stabil karena kehilangan elektronnya akan menerima elektron dari antioksidan. Secara alami, tubuh memiliki kemampuan untuk menghasilkan antioksidan, namun jika jumlah antioksidan tidak cukup melindungi sel tubuh dari jumlah radikal bebas yang tinggi maka kita memerlukan antioksidan dari luar seperti makanan. ${ }^{3}$

Salah satu contoh sumber antioksidan dari luar adalah Spirulina karena mengandung fikosianin. ${ }^{4}$ Spirulina terdiri dari beberapa jenis dan Spirulina yang sedang dikembangkan di Universitas Padjadjaran yaitu Spirulina platensis dan Spirulina fusiformis. Berdasarkan penelitian Wang et. al. menyatakan bahwa perbedaan jenis spesies Spirulina mempengaruhi kandungan komponen fikosianin sehingga mempengaruhi aktivitas antioksidannya. ${ }^{5}$

Aktivitas antioksidan S. platensis pernah dilaporkan oleh Barus dengan metode DPPH (1,1-diphenyl-2-piceylhydrazyl) memberikan aktivitas rendah karena tidak dilakukan ekstraksi terlebih dahulu saat analisis dan tidak melakukan pemurnian fikosianin. ${ }^{6}$ Penelitian lain yang dilakukan terhadap $S$. fusiformis juga mendapatkan hasil aktivitas antioksidan dengan kategori rendah yaitu memiliki persen penghambatan $5,920 \%$ pada konsentrasi ekstrak biomassa Spirulina 2000 ppm. ${ }^{7}$ Sedangkan pada dasarnya fikosianin yang berperan sebagai antioksidan merupakan kandungan pigmen tertinggi dalam Spirulina sp. yang mencapai $14-20 \%$ dari berat kering. ${ }^{8}$ Maka dari itu, dilakukan pengujian lebih lanjut mengenai aktivitas antioksidan dari kedua jenis Spirulina tersebut.
Pengujian aktivitas antioksidan pada penelitian ini menggunakan metode DPPH sebagai radikal bebas dan melihat perbandingan aktivitas antioksidannya. Metode DPPH merupakan metode yang sederhana, cepat dan mudah untuk screening aktivitas penangkap radikal beberapa senyawa. ${ }^{9}$ Penelitian ini dilakukan dengan memperbaiki metode sebelumnya melalui proses ekstraksi menggunakan pelarut aquades dan PBS (Phosphate Buffer Solution), lalu dilajutkan dengan fraksinasi ekstrak fikosianin sehingga diharapkan kemurnian ekstrak fikosianin dapat lebih tinggi dan dapat menunjukkan aktivitas antioksidan yang lebih besar dari kedua jenis Spirulina tersebut

Penelitian ini dilakukan pada bulan November 2015 hingga Maret 2016 di Laboratorium Pusat Penelitian dan Pengabdian Kepada Masyarakat departemen Analisis Farmasi dan Kimia Medisinal Universitas Padjadjaran.

\section{Metode}

\subsection{Alat dan Bahan}

Pada penelitian ini alat yang digunakan adalah Freeze dryer (Christ Alpha 1-2 LD), Sentrifugator (Hettich EBA 20), timbangan analitik (Dragon 204 dan Ohaus), spektrofotometer UV-VIS (Specord 200 analytik jena), Ultrasonik (Neyo), plastik selofan Shaker (IKA @260 Basic) dan alat-alat gelas yang umum digunakan di Laboratorium.

Bahan yang digunakan adalah Spirulina platensis dan Spirulina fusiformis, aquades, DPPH (1,1-diphenyl-2-picryl hydrazyl) (Merck), Ammonium sulfat (Merck), Potassium dihidrogen fosfat (Merck), disodium hidrogen fosfat (Merck), Vitamin $\mathrm{C}$, dan metanol pro analisis (Merck).

\subsection{Ektraksi Sel Spirulina}

Proses ekstraksi fikosianin dilakukan dengan menggunakan pelarut 0,1 M PBS dan aquades. Ekstraksi dan pemurnian fikosianin Spirulina dilakukan berdasarkan modifikasi metode yang dikembangkan oleh Hayashi et. al. dan Silveira et. al. ${ }^{10,11}$

Spirulina yang telah dikeringkan 
menjadi serbuk kering dilarutkan dengan masing-masing pelarut ekstraksi yang digunakan dengan konsentrasi masingmasing pelarut $4 \%(0,04 \mathrm{~g} / \mathrm{mL})$. Selanjutnya larutan disonikasi selama 30 menit dan shaker selama 24 jam. Larutan tersebut disentrifugasi $12.000 \mathrm{rpm}$, suhu $4^{\circ} \mathrm{C}$ selama 25 menit hingga menghasilkan suatu endapan dan supernatan. Fikosianin yang merupakan komponen yang terlarut dalam pelarut akan terakumulasi dalam supernatan yang dihasilkan. Kemudian, supernatan tersebut dipisahkan.

\subsection{Penyiapan Fraksi-fraksi Protein Kompleks \\ Supernatan yang dihasilkan selanjutnya} dilarutkan dengan larutan 0,025 M PBS untuk diendapkan dalam $30 \%$ dan $70 \%\left(\mathrm{NH}_{4}\right)_{2} \mathrm{SO}_{4}$. Prinsip pengendapan dengan ammonium sulfat berdasarkan pada kelarutan protein yang merupakan interaksi antara gugus polar dengan molekul air, interaksi ionik protein dengan garam dan daya tolak-menolak protein yang bermuatan sama. ${ }^{12}$ Endapan protein yang salah satu proteinnya adalah fikosianin dipisahkan melalui sentrifugasi pada kecepatan 12.000 rpm dengan suhu $4^{0} \mathrm{C}$ selama 10 menit. Kemudian, endapan tersebut dilarutkan dengan menggunakan 0,025 M PBS pH 7 untuk didialisis dengan menggunakan kantong selofan yang direndam dalam PBS 0,025 M pH 7 diatas penangas es. Dialisat yang dihasilkan dikeringbekukan menggunakan freeze dryer.

\subsection{Uji Rendemen dan Kemurnian Ekstrak} Fikosianin dalam Fraksi Protein Kompleks

Seluruh filtrat dari kedua jenis Spirulina ditimbang $0,05 \mathrm{~g}$ dan dilarutkan dengan 0,025 M PBS pH 7 sebanyak $500 \mu 1$ (konsentrasi 0,1 $\mu \mathrm{g} / \mathrm{ml})$. Setelah itu diencerkan menggunakan 0,001 M PBS pH 7 dengan pengenceran 10X. Uji kemurnian dan konsentrasi fikosianin ini dilakukan dengan melihat absorbansi pada panjang gelombang 280, 615, 620, dan $652 \mathrm{~nm}$. Untuk mengetahui rendemen dan kemurnian ekstrak fikosianin dapat diukur berdasarkan rumus berikut ini:

$$
\begin{gathered}
P C=\frac{A_{615 \mathrm{~nm}}-0,474\left(A_{652 \mathrm{~nm}}\right)}{5,34} \\
P P=\frac{A_{620 \mathrm{~nm}}}{A_{280 \mathrm{~nm}}}
\end{gathered}
$$

\section{PC : Phycocyanin Concentration}

PP : Phycocyanin Purity

Untuk menghitung hasil rendemen ekstraksi digunakan rumus :

$$
\text { yield }=\frac{\mathrm{PC} \times \mathrm{V}}{\text { Massa }}
$$

$\mathrm{V}$ adalah volume pelarut $(\mathrm{mL})$, dan massa adalah berat serbuk kering hasil pengendapan yang telah dikeringbekukan $(\mathrm{mg}) .{ }^{11}$

\subsection{Uji Aktivitas Antioksidan}

Pengujian aktivitas antioksidan

$S$. platensis dan $S$. fusiformis dilakukan dengan menggunakan DPPH mengacu pada metode Molyneux. ${ }^{13}$ Sampel uji yang merupakan hasil dari pengendapan yang telah dikeringbekukan ditimbang 0,05 g dan dilarutkan dalam metanol p.a $50 \mathrm{~mL}$ lalu diencerkan menjadi 200, 400, 600, dan $800 \mathrm{ppm}$. Sebagai pembanding, vitamin c 2,5 mg dilarutkan dalam metanol p.a $50 \mathrm{~mL}$ dan diencerkan menjadi 2,4,6, dan $8 \mu \mathrm{g} / \mathrm{mL}$. Pengukuran absorbansi sampel dilakukan dengan mencampurkan $2 \mathrm{~mL}$ larutan uji kedua jenis Spirulina dalam berbagai konsentrasi dengan larutan DPPH 40 ppm sebanyak 3 $\mathrm{mL}$, dan dibaca absorbansinya pada panjang gelombang maksimum yaitu $515 \mathrm{~nm}$. Harga $\mathrm{IC}_{50}$ dihitung dari kurva regresi linier antara \% inhibisi serapan dengan berbagai konsentrasi larutan uji dengan rumus :

$$
\% \text { inhibisi }=\left[1-\left(\frac{\text { A uji }}{\text { A kontrol }}\right)\right] \times 100 \%
$$

\section{Hasil}

3.1. Hasil Rendemen Ekstrak Fikosianin pada S. platensis dan S. fusiformis Setelah melakukan ekstraksi sel $S$. 
platensis dan S. fusiformis yang dilakukan dengan menggunakan berbagai macam pelarut, perhitungan rendemen dan kemurnian fikosianin dapat ditentukan melalui absorbansi yang dihasilkan pada panjang gelombang $620 \mathrm{~nm}$ yang merupakan karakteristik panjang gelombang fikosianin. ${ }^{13}$ Hasil rendemen ekstrak fikosianin pada kedua Spirulina ditampilkan pada Gambar 1. Dan hasil kemurnian fikosianin ditunjukan pada Gambar 2.

Hasil perhitungan kemurnian yang berasal dari rumus perbandingan abosbansi pada $620 \mathrm{~nm}$ dan abosrbansi $280 \mathrm{~nm}$ ekstrak fikosianin dapat dilihat Gambar 2.

3.2. Hasil Uji Aktivitas Antioksidan dari Fikosianin S. platensis dan S. fusiformis Hasil perhitungan nilai $\mathrm{IC}_{50}$ dari sampel ekstrak fikosianin S. platensis dan S. fusiformis, dengan pembanding sebagai kontrol positif adalah larutan vitamin $\mathrm{C}$ dapat dilihat pada Tabel 1.

\section{Pembahasan}

4.1. Rendemen Ekstrak Fikosianin pada S. platensis dan S. fusiformis

Berdasarkan pada Gambar 1, S. 30\% merupakan konsentrasi yang lebih fusiformis mengandung rendemen fikosianin dalam protein kompleks hasil fraksinasi lebih tinggi dibandingkan S. platensis pada kedua pelarut yang digunakan dengan konsentrasi pengendapan $\left(\mathrm{NH}_{4}\right)_{2} \mathrm{SO}_{2} 30 \%$ dibandingkan $\left(\mathrm{NH}_{4}\right)_{2} \mathrm{SO}_{4} 70 \%$.

Pelarut aquades dan PBS tidak memberikan perbedaan rendemen yang jauh dalam mengekstrak sel $S$. platensis maupun S. fusiformis untuk menghasilkan fikosianin dalam komplek protein yang diekstrak. Hal ini disebabkan karena kedua sifat pelarut tersebut adalah polar sesuai dengan sifat biomassa Spirulina yang juga polar sehingga kedua pelarut tersebut memiliki kemampuan yang hampir sama dalam mengekstrak sel Spirulina. ${ }^{14}$

Ammonium sulfat yang bersifat menarik air menjauh dari protein akan meningkatkan jumlah protein yang saling berinteraksi dan mengendap pada konsentrasi yang optimum. Meningkatnya jumlah konsentrasi ammonium sulfat juga meningkatkan jumlah protein yang mengendap, namun dengan bertambahnya konsentrasi ammonium sulfat tersebut tidak memberikan rendemen yang lebih baik. Konsentrasi ammonium sulfat 30\% merupakan konsentrasi yang lebih

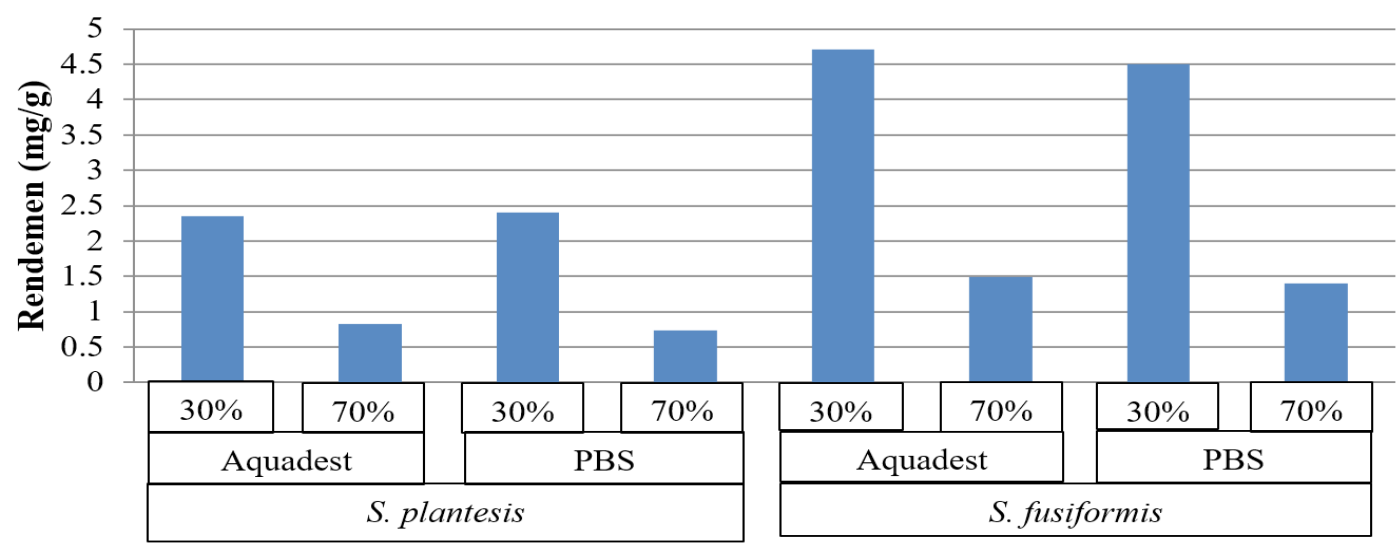

Jenis Metode Ekstraksi

Ket:

$30 \%$ : konsentrasi amonium sulfat yang digunakan adalah $30 \%$

$70 \%$ : konsentrasi amonium sulfat yang digunakan adalah $70 \%$

Aquadest : pelarut yang digunakan adalah aquadest

PBS : pelarut yang digunakan adalah PBS

S. plantesis : Spirulina yang diekstrasi adalah S. plantesis

S. fusiformis : Spirulina yang diekstraksi adalah S. fusiformis

Gambar 1. Hasil rendemen ekstrak fikosianin dalam protein kompleks pada S. plantesis dan S. fusiformis 


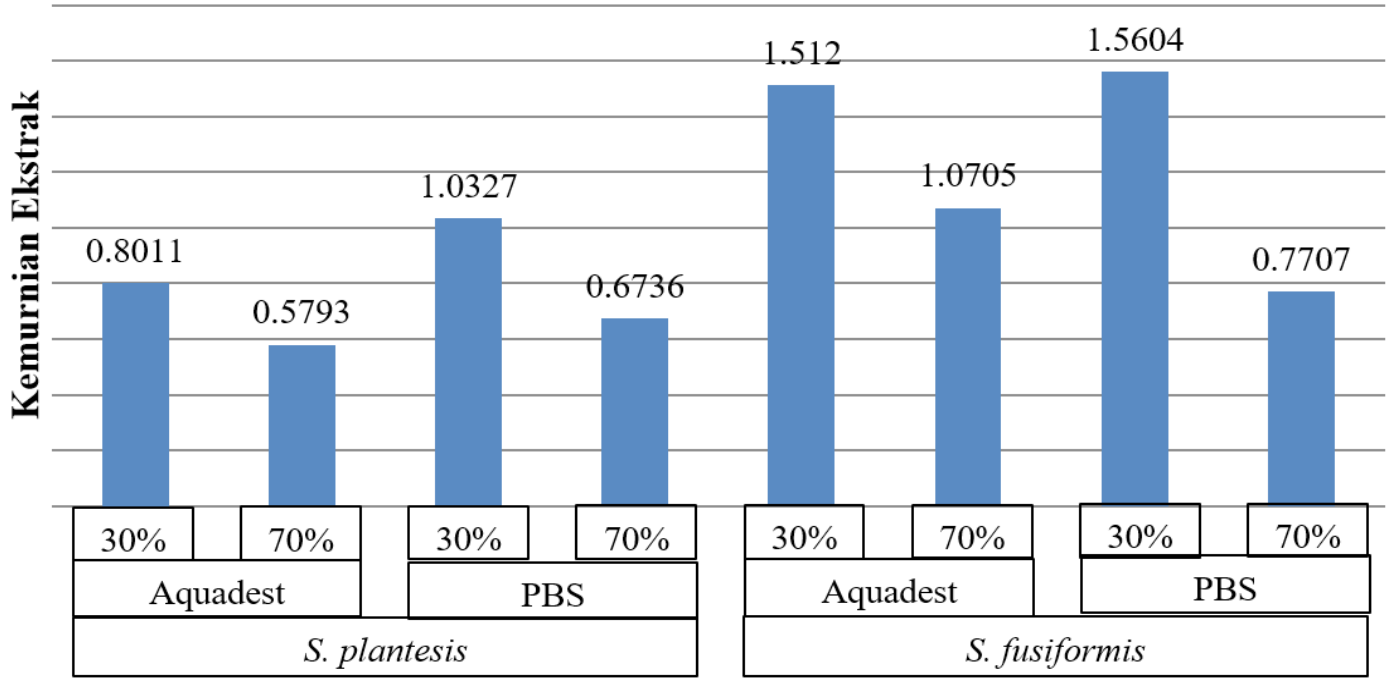

Jenis Metode Ekstraksi

Gambar 2. Hasil perhitungan kemurnian ekstrak fikosianin dari S. plantesis dan S. fusiformis

optimum dalam tahap awal fraksinasi ekstrak protein komplek yang mengandung fikosianin dibandingkan konsentrasi $70 \%$.

4.2. Hasil Perhitungan Kemurnian Ekstrak Fikosianin pada $S$. platensis dan $S$. fusiformis

Panjang gelombang $620 \mathrm{~nm}$ merupakan karakteristik panjang gelombang fikosianin sedangkan panjang gelombang $280 \mathrm{~nm}$ merupakan panjang gelombang dari protein. ${ }^{11}$ S. fusiformis memiliki kemurnian ekstrak fikosianin lebih tinggi dibandingkan $S$. platensis pada kedua pelarut yang digunakan dengan konsentrasi pengendapan $\left(\mathrm{NH}_{4}\right)_{2} \mathrm{SO}_{2}$ $30 \%$ dibandingkan $\left(\mathrm{NH}_{4}\right)_{2} \mathrm{SO}_{4} 70 \%$.

Kemurnian ekstrak fikosianin pada kedua jenis Spirulina menghasilkan nilai yang lebih tinggi pada pelarut PBS dibandingkan aquades. Ini menunjukan bahwa pelarut PBS menarik fikosianin lebih murni dibandingkan pelarut aquades pada kedua jenis Spirulina. Hal ini didukung oleh Satyantini, et al. yang menyatakan bahwa pelarut buffer fosfat adalah pelarut terbaik untuk ekstraksi fikosianin. ${ }^{15}$

Apabila dibandingkan dengan nilai

Tabel 1. Nilai IC50 Sampel dan Pembanding

\begin{tabular}{ccccc}
\hline Sampel Uji & Kons. (ppm) & $\begin{array}{c}\text { Persen Inhibisi } \\
(\mathbf{\%})\end{array}$ & $\begin{array}{c}\text { Persamaan Regresi } \\
\text { Linier }\end{array}$ & IC50 (ppm) \\
\hline \multirow{3}{*}{ Spirulina } & 200 & 33,16 & $\mathrm{y}=0,0856 \mathrm{x}+16,842$ & 387,36 \\
plantesis & 400 & 52,09 & & \\
& 600 & 68,74 & $\mathrm{R}=0,9985$ & \\
& 800 & 84,69 & & \\
Spirulina & 200 & 44 & $\mathrm{y}=0,0823 \mathrm{x}+24,369$ & \\
fusiformis & 400 & 55,94 & & \\
& 600 & 67,91 & $\mathrm{R}=0,9558$ & \\
& 800 & 94,54 & & \\
Vitamin C & 2 & 12,59 & $\mathrm{y}=11,429 \mathrm{x}-7,2743$ & \\
(Pembanding) & 4 & 37,87 & & \\
& 6 & 71,33 & $\mathrm{R}=0,9442$ & \\
\hline
\end{tabular}


kemurnian ekstrak fikosianin dari penelitian yang dilakukan oleh Satyantini, et al. yang mendapatkan hasil sebesar 0,9024 pada $S$. platensis dengan pelarut $\mathrm{PBS}$, nilai kemurnian esktrak fikosianin yang diperoleh dari $S$. platensis maupun $S$. fusiformis pada pelarut PBS memberikan nilai yang lebih tinggi. Satyantini, et al. melakukan ekstraksi fikosianin pada suhu ruang. ${ }^{16}$ Sedangkan penelitian ini dilakukan pada suhu yang dijaga tetap rendah $\left( \pm 4^{\circ} \mathrm{C}\right)$. Hal tersebut diduga karena fikosianin merupakan pigmen protein yang kestabilannya sangat dipengaruhi oleh suhu dan $\mathrm{pH}$ dan sifat fikosianin yang tidak stabil pada suhu tinggi sehingga ekstraksi fikosianin pada suhu rendah lebih efisien dibandingkan suhu ruang yang lebih tinggi. ${ }^{17}$

4.3. Hasil Uji Aktivitas Antioksidan dari Fikosianin S. platensis dan S. fusiformis Optimasi pengukuran senyawa antiradikal DPPH dilakukan dengan penentuan panjang gelombang maksimum yang diperoleh yaitu pada $515 \mathrm{~nm}$, operating time larutan DPPH dalam methanol yaitu 3540 menit, dan waktu inkubasi untuk vitamin $\mathrm{C}$ dan fikosianin adalah 90 menit.

Parameter yang digunakan dalam aktivitas antioksidan dengan menggunakan DPPH adalah $\mathrm{IC}_{50}$ atau Inhibition Concentration yaitu konsentrasi ekstrak yang mampu meredam aktivitas DPPH sebanyak $50 \%$.

Berdasarkan hasil tersebut S. fusiformis yang memiliki kemurnian ekstrak fikosianin lebih tinggi dibandingkan $S$. platensis juga memiliki aktivitas antioksidan yang lebih tinggi. Sedangkan vitamin c menghasilkan $\mathrm{IC}_{50}$ yang jauh lebih kecil dibandingkan kedua jenis Spirulina tersebut, hal ini disebabkan karena vitamin $\mathrm{C}$ merupakan senyawa yang murni dibandingkan dengan zat aktif fikosianin dari Spirulina.

Hasil aktivitas antioksidan pada $S$. fusiformis pada penelitian ini menghasilkan nilai yang lebih besar dibandingkan penelitian sebelumnya yang dilakukan Saputra dengan hasil persen inhibisi 5,920\% pada konsentrasi 2000 ppm. Sedangkan pada penelitian ini persen inhibisi sudah mencapai $>30 \%$ pada konsesntrasi 200 ppm. Hal ini disebabkan karena pada penelitian ini dilakukan tahap awal pemurnian fikosianin melalui fraksinasi ekstrak fikosianin dengan menggunkan $\left(\mathrm{NH}_{4}\right)_{2} \mathrm{SO}_{2}$ dan dialisis sehingga memberikan aktivitas antioksidan yang jauh lebih besar dan dilakukan pula tahap pemurnian fikosianin sehingga memberikan aktivitas antioksidan yang jauh lebih besar

\section{Simpulan}

Metode ekstraksi menggunakan pelarut PBS (Phosphate Buffer Solution) 0,1 M pH 7 merupakan metode yang paling efektif dengan pengendapan ammonium sulfat $30 \%$ yang menghasilkan nilai kemurnian ekstrak fikosianin tertinggi yaitu 1,5604 pada Spirulina fusiformis dan 1,0327 pada Spirulina platensis.

Berdasarkan pengujian aktivitas antioksidan menggunakan metode DPPH, Spirulina fusiformis memiliki aktivitas antioksidan yang lebih tinggi dibandingkan dengan Spirulina platensis dengan nilai 311,43 ppm dan 387,36 ppm masing-masingnya.

\section{Daftar Pustaka}

1. Winarsi, H. Antioksidan Alami dan Radikal Bebas: Potensi dan Aplikasinya dalam Kesehatan. Yogyakarta: Kanisius. 2007 : 13-15

2. Kumalaningsih, Sri. Antioksidan AlamiPenangkal Radikal Bebas. Surabaya: Trubus Agrisarana. 2006;7-86.

3. Benedetti S, Benvenuti F, Pagliarani S, Francogli S, Scoglio S, Canestrari F. Antioxidant properties of a novel phycocyanin extract from blue-green alga Aphanizomenon flos-aquae. Life Sciences. 2004;75: 2353-2362.

4. Chopra K, Bishnoi M. Antioxidant profile of Spirulina: a blue green microalga. Perancis: CRC Press. 2007;100:11371143

5. Wang L, Pan B, Sheng J, Xu J, Hu Q. Antioxidant activity of Spirulina platensis extracts by supercritical carbon dioxide extraction. Food Chemistry. 2007;105: 36-41.

6. Barus, Dita Agustina. Kandungan 
Fikosianin, Protein, Dan Antioksidan Spirulina platensis Yang Ditumbuhkan Dalam Media Dan Umur Kultivasi Berbeda. (Skripsi). Bogor: Program Studi Teknologi Hasil Perikanan Fakultas Perikanan dan Ilmu Kelautan Institut Pertanian Bogor. 2013.

7. Saputra, Andika Tri. Komposisi Kimia Dan Pigmen Spirulina Fusiformis Pada Umur Panen Yang Berbeda. (Skripsi). Bogor: Program Studi Teknologi Hasil Perikanan Fakultas Perikanan dan Ilmu Kelautan Institut Pertanian Bogor. 2009.

8. McCarty, M.F. Clinical potential of spirulina as a source of phycocyanobilin. Journal of Medicinal Food. 2007;10(4): 566-570.

9. Marxen, K., Heinrich, K., Lippemeier, S., Hintze, R., Ruser, A., dan Hansen,U. Determination ofDPPHRadicalOxidation Caused by Methanolic Extracts of Some Microalgal Species by Linear Regression Analysis of Spectrophotometric Measurements. Sensors. 2007;7:20802095.

10. Hayashi, O., S. Ono, K. Ishii, Y.H. Shi, T. Hirahashi and T Katoh. Enhancement of proliferation and differentiation in bone marrow hematopoietic cells by Spirulina (Arthrospira) platensis in mice. Journal of Applied Phycology. 2006;18:47-56.

11. Silveira, S.T., J.F.M Burkert, J.A.V Costa, C.A.V Burkert and S.J Kalil.
Optimization of phycocyanin extraction from Spirulina platensis using factorial design. Bioresources Technology. 2007;98: 1629-1634.

12. Lehninger, Albert. Dasar-Dasar Biokimia Jilid 1. Jakarta: Erlangga. 2008; 877-939

13. Molyneux P. The use of stable free radical diphenylpicrylhydrazyl (DPPH) for sstimating antioxidant activity. Journal of Science Technology. 2004;26: 211-219.

14. Boussiba, S; Richmod, A. Isolation and Purification of Phycocyanin from the Blue Green Alga Spirulina platensis. Arch Microbiol. 1979;120:155-159.

15. Arlyza, I.S. Isolasi Pigmen Biru Phicocyanin dari Mikroalga Spirulina platensis. Oseanologi dan Limnoogi. Indonesia. 2005;38:79-92

16. Satyantini, Woro H., Sukenda, Enang Harris, dan Nur Bambang P. Teknik Produksi, Ekstraksi Dan Karakterisasi Fikosianin Spirulina platensis Sebagai Bahan Imunostimulan. Oseanologi dan Limnologi di Indonesia. 2014;40(2): 119131

17. Yan, S., Zhu LP, Su HN, Zhang XY, Chen XL, Zhou BC, Zhang YZ. Singlestep chromatography for simultaneous purification of C-phycocyanin and allophycocyanin with high purity and recovery from Spirulina (Arthrospira) platensis. J. Appl. Phycol. 2011.; 23: 1-6. 